\title{
International Commercial Courts in France: Innovation without Revolution?
}

\author{
Alexandre Biard*
}

\section{Abstract}

In 2018, in the wake of Brexit, the French legal profession took several important measures to strengthen the competitiveness of France and the French legal system, and to make Paris an attractive go-to-point for businesses when the latter have to deal with international commercial litigation. When taking a closer look at it, Brexit is only the top of the iceberg, and has mostly served as a catalyst. Reasons explaining the development of international commercial courts in France are manifold. They are consequences of long-standing efforts aimed at boosting the French judicial marketplace to adapt it to the requirements of globalization and to the expectations of multinational corporations. The setting-up of the French international business courts has made several procedural adjustments necessary.Although the latter undoubtedly represent clear innovations, they however do not constitute a full-blown revolution. France has indeed decided to maximize already-existing procedural rules, combined with a new organisational format inspired by the Common Law tradition. If it remains too early to draw clear conclusions on the impact of these new developments, it is essential to keep our ears to the ground, and to be forwardlooking. We should carefully consider the possible sideeffects on the French justice system considered as a whole, and in particular wonder whether these international commercial courts might in the future open the door to broader far-reaching evolutions within the judicial system. Finally, the multiplication of international business courts across Europe nowadays triggers some questions concerning the role and potential added value of an EU initiative in this domain.

Keywords: international commercial court, dispute resolution, business court, Brexit, judicial system

In 2018, the French legal profession took several important measures to strengthen the competitiveness of France and the French legal system, and to make Paris an attractive go-to point for businesses when confronted with international commercial litigation. In February 2018, the Paris Court of Appeal inaugurated a new specialised chamber dedicated to international commercial

\footnotetext{
Postdoctoral researcher, Erasmus University Rotterdam (biard@law.eur.nl). The research leading to these results has received funding from the European Research Council - ERC Consolidator grant agreement no. 726032 (Building EU Civil Justice: Challenges of Procedural Innovations Bridging Access to Justice, available at: www.euciviljustice.eu. I thank Ms Schaller for the additional information on the functioning of the ICCP-CA and the two anonymous reviewers for their useful comments on previous drafts (last updates: January 2019).
}

disputes (Chambre commerciale internationale de la Cour d'appel de Paris, CCIP-CA in French or ICCP-CA in English). Representatives of the Paris Bar and the judiciary signed a protocol setting forth the ICCP-CA's new rules of procedure. ${ }^{1}$ The effective launch of the ICCPCA was relatively smooth and quick. It notably avoided the meanders and delays arising out of lengthy parliamentary discussions and political controversies experienced by other European countries currently engaged in the process of establishing international commercial courts. ${ }^{2}$ In parallel, the Paris Commercial Court (Tribunal de commerce de Paris) also renewed the rules of procedure of its existing International and European Chamber (Chambre internationale et européenne, CIE). ${ }^{3}$ Both protocols entered into force on 1 March 2018. The French Ministry of Justice has published on its website a brochure, available in both French and English, presenting the functioning of the two international com-

1. Protocole relatif à la procédure devant la Chambre Internationale de la Cour d'appel de Paris, available at: www.avocatparis.org/system/files/ editos/protocoles_signes_creation_juridiction_commerciale_internationa le_1.pdf (last visited January 2019) (hereafter ICCP-CA Protocol). English translation available at: www.cours-appel.justice.fr/sites/default/ files/2018-06/CICAP_English_Protocole \%20barreau\%20de\%20Paris \%20-\%20Cour\%20d'appel\%20de\%20Paris_mai2018.pdf (last visited January 2019).

2. See e.g. in Belgium: Conseil Superieur de la Justice, 'Avis d'office sur I'avant-projet de loi instaurant la Brussels International Business Court', 14 March 2018, available at: www.hrj.be/sites/default/files/ press_publications/avis-bibc-fr.pdf (last visited January 2019); ‘Le Brussels International Business Court, le tribunal cinq étoiles qui fait grincer des dents les magistrats', Le Vif, 22 August 2018, available at: www.levif.be/actualite/belgique/le-brussels-international-businesscourt-le-tribunal-5-etoiles-qui-fait-grincer-les-dents-des-magistrats/ article-normal-878515.html (last visited January 2019). In the Netherlands, the Netherlands Commercial Court (NCC) was initially expected to start its activities in July 2018, but the adoption of the draft legislation was postponed to the winter of 2018 (G. Antonopoulou, E. Themeli \& X. Kramer, 'This One Is Next: The Netherlands Commercial Court!', 8 March 2018, available at: http://conflictoflaws.net/2018/ this-one-is-next-the-netherlands-commercial-court/ (last visited January 2019); F. Henke, 'Netherlands Commercial Court: English Proceedings in the Netherlands', 25 October 2018, available at: http:// conflictoflaws.net/2018/netherlands-commercial-court-englishproceedings-in-the-netherlands/(last visited January 2019).

3. 'Protocole relatif à la procédure devant la Chambre Internationale du Tribunal de Commerce de Paris', available at: https://www.coursappel.justice.fr/sites/default/files/2018-06/CICAP_Protocole \%20barreau\%20de\%20Paris\%20-\%20Tribunal\%20de\%20commerce $\% 20 d e \% 20$ Paris.pdf, (last visited January 2019) (hereafter 'CIE Protocol'). English translation available at: www.foleyhoag.com/-/media/ files/foley\%20hoag/event/2018/protocol-on-procedural-rulesapplicable-to-the-international-chamber-of-the-paris-commercialcourt.ashx?la=en (last visited January 2019). 
mercial courts. ${ }^{4}$ By December 2018, seventeen cases had been filed before the ICCP-CA, and hearings of two of them had taken place. $^{5}$

It is commonly acknowledged today that when dealing with cross-border commercial matters courts not only deliver justice but also act as service providers, competing with each other to be selected by parties as a dispute resolution forum for their contractual arrangements. ${ }^{6}$ This competition has materialised in many different ways: from marketing strategies with the publication of brochures advertising the strengths of national courts and legal systems ${ }^{7}$ to more structural changes through the creation of new international commercial courts. In recent years, the competition between jurisdictions has significantly accelerated owing to the decision of the UK to leave the European Union (EU) (Brexit). This event has served as a catalyst, and many European countries have regarded Brexit as an invaluable opportunity to promote their national systems. Brexit has thus stirred legal innovations among member states wishing to propose alternative venues to London, the latter being, for long, considered one of the leading international commercial litigation hubs worldwide. As the High Legal Committee for Paris Financial Markets (Haut Comité Furidique pour la Place Financière de Paris, HCJP $)^{8}$ highlighted, 'there is a worldwide, as well as European, competition between courts .... In order to protect the sovereignty of our judicial system and for economic reasons, ... French courts with jurisdiction in various business law matters should [preserve] their authority and attractiveness [through] the quality of the services they provide.' 9

4. Ministère de la Justice, 'International Commercial Courts of Paris (ICCP),' 2018, available at: https://www.cours-appel.justice.fr/sites/ default/files/2018-08/Leaflet_CCIP_180629_V11.pdf (last visited January 2019).

5. As indicated by an ICCP-CA judge.

6. E. Themeli, Civil Justice System Competition in the European Union The Great Race of Courts (2018), at 368; H. Kötz, 'The Jurisdiction of Choice: England and Wales or Germany?', 18 European Review of Private Law, at 94-108 (2010).

7. The Law Society of England and Wales and its partners published in 2007 'England and Wales: the Jurisdiction of Choice', available at: www.eversheds-sutherland.com/documents/

LawSocietyEnglandAndWalesJurisdictionOfChoice.pdf (last visited January 2019) followed in 2016 by 'England and Wales: Global Legal Centre', available at: www.lawsociety.org.uk/policy-campaigns/campaigns/ global-legal-centre (last visited January 2019), and in 2017 'English Law, UK Courts and UK Legal Services after Brexit - the view beyond 2019', available at: www.chba.org.uk/news/brexit-memo (last visited January 2019), the German legal profession published in 2009 'Law made in Germany', available at: www.lawmadeingermany.de/LawMade_in_Germany_EN.pdf (last visited January 2019), and the Fondation pour le droit continental/Civil Law initiative issued in 2011 a document entitled 'Continental Law: Global, Predictable, Flexible, CostEffective', available at: www.kontinentalesrecht.de/tl_files/kontinentalbase/Broschuere_FR.PDF (last visited January 2019).

8. HCJP was the entity entrusted by the French Ministry of Justice for making propositions for the creation of international commercial courts in France.

9. HCJP, 'Recommendations for the creation of special tribunals for international business disputes', 3 May 2017, available at: https:// publications.banque-france.fr/sites/default/files/rapport_07_a.pdf (last visited January 2019) (hereafter 'Recommendations').
Brexit is, however, only the tip of the iceberg. This article shows that the drivers of the development of international commercial courts ${ }^{10}$ in France are manifold and by no means recent. They are the consequences of longstanding efforts aimed at boosting the French judicial marketplace to adapt it to the requirements of globalisation and to the expectations of multinational corporations (1). The setting up of the French international commercial courts has made several procedural adjustments necessary. Although these adjustments undoubtedly represent clear innovations, they do not constitute a full-blown revolution: France has indeed decided to maximise the existing procedural rules, together with developing a new organisational format inspired by the common law tradition (2). Although it is too early to clearly assess the impact of these new courts, it is essential to keep our ears to the ground and to be forwardlooking. We should carefully consider the possible side effects on the French justice system as a whole and, in particular, reflect on whether these international commercial courts might, in the future, open the door to a broader, far-reaching evolution within the judicial system. Finally, the future role and possible added value of the EU in the context of the multiplication of European business courts should be explored further (3). Readers should note that this article does not intend to describe all the procedural technicalities of the French international commercial courts but rather to look at the broader picture. Therefore, it discusses the development of these business courts as essentially a matter of innovative judicial policy.

\section{Rationale: Brexit and Beyond}

\subsection{Contextual Reason: Brexit as Catalyst}

Brexit is a source of uncertainty for all stakeholders, as no one has a clear view on the future of the relationship between the EU and the UK. ${ }^{11}$ However, it can be predicted that the event will be highly disruptive. Deep changes within the EU as well as a reorganisation of roles and influences between EU member states can be expected in the coming years. ${ }^{12}$ As part of a broader research agenda investigating the consequences of Brexit, ${ }^{13}$ in December 2016, HCJP launched a working group to examine the potential impact of Brexit on judicial cooperation in civil and commercial matters. The final report was published in January $2017 .{ }^{14}$ As the

10. In this article, the term 'international commercial courts' refers to the new international commercial chambers established in pre-existing courts.

11. Financial Times, 'Counting the Cost of Brexit Uncertainty', 7 September 2018.

12. H. Eidenmüller, 'Collateral Damage: Brexit's Negative Effects on Regulatory Competition and Legal Innovation in Private Law', ZEuP, 4/2018, at 868-91; O. Patel and A. Renwick, 'Brexit: The Consequences for other EU Member States', 2016, UCL Constitution Unit Briefing Paper.

13. HCJP's opinions and reports on Brexit are available at: hcjp.fr/opinionsand-reports-copier/ (last visited January 2019).

14. HCJP, 'Report on the Implications of Brexit on Judicial Cooperation in Civil and Commercial Matters', 30 January 2017, available at: https:// 
report highlighted, the attractiveness of London as a dispute resolution forum for commercial litigation can be explained by various factors pertaining to the peculiarities of the English judicial system and English law as well as to the UK's participation in the European Judicial Cooperation area. The UK is, indeed, commonly regarded as having a clear, solid and predictable dispute resolution system for businesses. The use of the English language as lingua franca and the methods applied by courts when interpreting commercial contracts - viewed as being rigorously literal (in contrast to French courts, which are often criticised for interpreting contractual terms) - tend to provide certainty and visibility for businesses. In parallel, English commercial law and the English judiciary are also good incentives for businesses when bringing their disputes to the UK. ${ }^{15}$ A 2015 study, commissioned by the UK Ministry of Justice and conducted by the British Institute of International and Comparative Law (BIICL), explored the main reasons why London has become 'a popular and natural jurisdiction for the litigation of high-value cross-border disputes'. ${ }^{16}$ The reasons included, notably, the reputation and experience of English judges and the use of English law, described as 'the prevalent choice of applicable law in international commercial transactions due to its quality, certainty and efficiency in commercial disputes' ${ }^{17}$ Other reasons included efficient remedies, procedural effectiveness and forum neutrality. As an observer highlighted in 2017, '... they come here to access the law. They come here to deal with a situation where the courts provide certainty and fairness, and where the judiciary has a very strong reputation for impartiality. We believe very strongly that this is not just about the legal services industry itself but about the underpinning that English law gives the wider economy and business relations'. 18

In parallel, the UK has benefited from the access to the European judicial area and its associated advantages. Several EU arrangements have facilitated the portability and recognition of UK judgements across the EU and of EU member states' court decisions in the UK. Businesses are assured that their rights and interests will be protected under equivalent conditions before all courts

publications.banque-france.fr/sites/default/files/rapport_05_a.pdf (last visited January 2019).

15. G. Hannotin, 'Réforme de la procédure civile : le modèle anglais comme source d'inspiration?', Recueil Dalloz, 2018, at 1213.

16. E. Lein, R. Mc Corquodale, L. Mc Namara, H. Kupelyants \& J. del Rio, 'Factors Influencing International Litigants' Decisions to Bring Commercial Claims to the London-based Courts', 2015, available at: https:// assets.publishing.service.gov.uk/government/uploads/system/uploads/ attachment_data/file/396343/factors-influencing-internationallitigants-with-commercial-claims.pdf (last visit January 2019).

17. Ibid

18. House of Commons, 'Implications of Brexit for the justice system', 22 March 2017, available at: https://publications.parliament.uk/pa/ cm201617/cmselect/cmjust/750/750.pdf (last visited January 2019) (hereafter 'House of Commons Report'); M. Requejo, 'Immediate Consequences on the London Judicial Market', Blogpost Conflict of Laws, available at: http://conflictoflaws.net/2016/brexit-immediateconsequences-on-the-london-judicial-market/ (last visited January 2019). of the other EU member states, and under the supervision of EU institutions. ${ }^{19}$ Surely, Brexit will reshuffle the existing framework and affect the attitudes of businesses, ${ }^{20}$ albeit the ways by which and the extent to which this will happen is still unclear. Some have taken the view that Brexit will not negatively impact the UK's position as a main venue for the resolution of international commercial disputes. ${ }^{21}$ Others, however, tend to consider that Brexit might lead to 'a transfer to the EU of some legal and judicial activities currently centred in the UK' ${ }^{22}$ A UK practitioner, for instance, pointed out that 'the portability of English judgements and having them automatically recognised within the EU is a considerable advantage. There is a risk-it is not clear how high the risk is - that they are no longer going to be recognised and enforced in the same way, at least in some places. It may be a theoretical risk, but commercial parties do not like risks'. ${ }^{23}$ Substantiating the second point of view, a study conducted in the summer of 2018 brought evidence of recent shifts in the behaviour of businesses, and revealed that around $35 \%$ of businesses are now preferring EU courts over the UK courts owing to the uncertainty associated with Brexit. ${ }^{24}$

Anticipating a possible weakening of London as a go-to litigation centre for international commercial disputes, HCJP investigated possible tools to increase the attractiveness of Paris as an alternative. While contemplating Brexit as 'a unique opportunity' for France, the French Ministry of Justice called on HCJP to make recommendations for 'rapidly setting up judicial tribunal sections, within specifically designated courts, capable of hearing technical disputes, applying foreign law principles, and holding proceedings under the most efficient conditions, in particular with respect to language, with the aim of offering economic operators the possibility, in the event of a dispute, to submit their matter to courts in France able to readily decide cases applying the law they have chosen, in the language of their business relation-

19. HCJP, 'Report on the Implications of Brexit on Judicial Cooperation in Civil and Commercial Matters', 30 January 2017 (referred to as HCJP Brexit Report henceforth).

20. R. Aikens and A. Dinsmore, 'Jurisdiction, Enforcement and the Conflict of Laws in Cross-border Commercial Disputes: What Are the Legal Consequences of Brexit?', 27 European Business Law Review (2016); A. Dickinson, 'Back to the Future: The UK's EU Exit and the Conflict of Laws', 12 Journal of Private International Law, 195 (2016).

21. Cornerstone Research, Fighting Strong - The Annual Commercial Dispute Resolution Survey (2016) 2nd ed., available at: www.cornerstone.com/Publications/Articles/Commercial-DisputeResolution-Survey-2016 (last visited January 2019).

22. HCJP Brexit Report, above n. 19 also referring to: Bar Council Brexit Working Group, the Brexit Papers, 2016, at 11, available at: www.barcouncil.org.uk/media/508513/the_brexit_papers.pdf (last visited January 2019); Eidenmüller, above n. 12.

23. House of Commons Report, above n. 18, at 15.

24. Thomson Reuters, 'The Impact of Brexit on Dispute Resolution Clauses', July 2018, available at: www.thomsonreuters.com/en/press-releases/ 2018/july/35-percent-of-businesses-choosing-eu-courts-over-uk-dueto-brexit-uncertainty.html (last visited January 2019); Law Society Gazette, 'Businesses Shun UK Courts in Drove as Brexit Looms', 23 July 2018, available at: www.lawgazette.co.uk/businesses-shun-uk-courtsin-droves-as-brexit-looms/5066997. article (last visited January 2019). 
ship'. ${ }^{25}$ In May 2017, HCJP published forty-one propositions for the creation of specialised courts for international commercial disputes. These propositions covered many different topics, including appropriate language rules, eligible disputes, judicial organisational rules, revision of procedural standards, as well as material and human resources required for the effective functioning of these new international chambers. ${ }^{26}$

\subsection{Structural Reasons: Boosting the French Judicial System}

Beyond Brexit, several structural reasons have triggered the creation of the French international commercial chambers. One of them is the necessity to adapt the French legal and judicial system to facilitate the treatment of ever-increasing complex international commercial cases. In 2012, for example, a practitioner argued that foreign companies with experience in litigation in France were often not satisfied and usually unwilling to repeat a similar experience. ${ }^{27}$ From the point of view of foreign parties, there may be several reasons for France's limited attractiveness. For example, the role of experts is idiosyncratic in France, when compared with other jurisdictions, where experts are appointed by parties and play significant roles during the resolution of the dispute. As practitioners have explained, 'in French litigation, a court will almost never consider a scientific or other specialised question based only on the parties' submissions and without an opinion from a neutral expert whom the court has appointed to provide views on the issue .... The short of it is that the expertise is only as good as the expert who runs it; the quality of the expert is to a great extent unpredictable (...). While this system is intended to provide assurance that experts are always knowledgeable in the fields for which the court appoint them, reality sometimes falls short of this objective'. ${ }^{28}$ Practitioners have also observed that 'in larger cases, it is not uncommon for judges to ignore or even expressly set aside expert reports that they find uncon-

25. HCJP, 'Préconisations sur la mise en place à Paris de chambres spécialisées pour le traitement du contentieux international des affaires', 3 May 2017 (see Appendix 1, 'Lettre de saisine adressée par le Garde des Sceaux-Ministre de la Justice au Haut Comité Juridique de la Place Financière de Paris', 7 March 2017, available at: https:// publications.banque-france.fr/sites/default/files/rapport_07_f.pdf (last visited January 2019).

26. O. Dufour, 'Justice financière : Paris se rêve place de droit sur fond de Brexit', 109 Petites Affiches 4 (2018); O. Akyurek, 'La création de chambres commerciales internationales, outil de renforcement de la place de Paris', 138 Petites Affiches 18 (2018); 'Paris juridiction internationale', 9 Petites Affiches 3 (2018).

27. T. Baudesson, 'Le contentieux international devant les juridictions françaises', Recueil Dalloz 2232 (2012) (in French: 'Les grandes entreprises internationales gèrent des contentieux partout dans le monde et nombreuses sont celles qui, ayant connu l'expérience d'un contentieux en France, sont peu désireuses de renouveler l'expérience. Les décideurs publics ne sont pas véritablement conscients de cette mauvaise perception et ne mesurent pas les conséquences du benchmarking mondial qui est en train de s'opérer entre les grandes places du droit')

28. Brochure prepared by Debevoise and Plimpton, '10 things U.S. Litigators Should Know About Court Litigation in France', 2017, at 21-22, available at: www.debevoise.com/ /media/email/documents/ 2017/10_things_us_litigators_should_know_about_court_litigation_in_f rance.pdf (last visited January 2019). vincing ... ${ }^{29}$ In parallel, the limited implication of the judge before hearings is often puzzling for foreign litigants, and seen as a cause of delays and uncertainty during the proceedings. As a general rule, the pre-trial phase (mise en état) is not intended to discuss the merits of the case (even though some issues may occasionally arise with consequences on the merits). Therefore, 'parties should not count on extensive conversations with the court at the procedural conferences that punctuate the pre-trial phase. Except if some of the procedural questions ... are raised, parties have very few communications with the judge during the pre-trial phase. During the procedural conferences, and especially commercial conferences, the speaking time of the attorneys is very limited, less than a minute generally'. ${ }^{30} \mathrm{HCJP}$ also noted that the 'minimalist approach to proceedings, [which] can be explained by the needs to deal with a volume of litigation that exceeds the capacity of the courts, ... disconcerts foreign litigants who are used to more detailed case preparation and hearings in Common Law courts, and who may view our judging methods as superficial. In addition, [deadlines] that are not met and erratic hearing dates generate uncertainty about the foreseeable timeframe'. 31

The rise of the French international commercial courts can also be regarded as an effort to consolidate and boost the existing - albeit incomplete - judicial architecture. In 2010, the Paris Commercial Court officially inaugurated its International and European Chamber (Chambre internationale et européenne, CIE). Although the chamber existed well before $2010,{ }^{32}$ foreign litigants were often unaware of its existence. As the former president of the court acknowledged, the official launch of the CIE and its accompanying media coverage aimed at putting the CIE in the limelight. ${ }^{33}$ The chamber is composed of judges who have experience in international business law. The use of foreign language is permitted, but, until recently, the conditions under which foreign languages could be used were not precisely described. As the HCJP reported, although the court does not keep statistics, 'the Chief Judge of the Court estimates that hearings are partially held in a foreign language in only a few cases each year'. ${ }^{34}$ In 2018, the president of the Paris Commercial Court and representatives of the Paris Bar signed a protocol revising and consolidating the functioning of the CIE. The protocol contains clearer rules on (among other things) the use of English at various

29. Ibid., at 26 .

30. Ibid., at 19

31. HCJP Brexit Report, above n. 19, at 19.

32. The Paris commercial Court created an international Chamber in 1995. In 2015, the international Chamber merged with the European Chamber (created in 1999), available at: www.foleyhoag.com/-/media/files/ foley\%20hoag/event/2018/protocol-on-procedural-rules-applicableto-the-international-chamber-of-the-paris-commercial-court.ashx? la=en (last visited January 2019). See also E. Vasseur and J. Bouyssou, 'La France et les diverses initiatives de jurisdictions internationales', L'Observateur de Bruxelles, 114 (2018), at 10-12.

33. Fondation pour le droit continental, 'Lettre d'information', December 2010, available at: www.fondation-droitcontinental.org/fr/wp-content/ uploads/2013/12/decembre-2010.pdf (last visited January 2019).

34. HCJP Brexit Report, above n. 19, at 28. 
stages of the proceedings, submission of evidence, witness testimony and organisation of oral proceedings.

As the president of the Paris Commercial Court put it, before the creation of the ICCP-CA, the CIE 'felt a bit lonely', ${ }^{35}$ as there was no specialised section at the appeal court level. Arguably, if the objective is to establish a fully-fledged architecture for international business litigation, one may also wonder whether a specialised international chamber at the level of the Court of cassation (Cour de cassation) would also be needed. This evolution is currently not foreseen. However, some adjustments may be necessary in the practices of the three chambers of the Court of cassation handling cases from the CIE and the ICCP-CA. The future will show how the Court of cassation has adapted its behaviour to the practices of the international commercial courts. Finally, it should be noted that Paris is already an important centre for international arbitration. This is because the International Chamber of Commerce (ICC) is based in Paris and its International Court of Arbitration (ICA) is often chosen by multinational corporations. In 2011, a report suggested several adjustments to reinvigorate Paris as a centre for arbitration. ${ }^{36}$ Recent measures promoting specialised business courts can thus be regarded as similar initiatives, although this time they are happening in the judicial arena. All of them aim to further enhance the attractiveness of Paris as a venue for resolving international commercial disputes.

\section{Procedural Changes: Innovating Without Revolutionising}

\subsection{Legal Transplants and Rediscovery of the Wheel}

Following the terminology coined by Watson in the 1970 s, the setting up of international commercial courts can be a fertile ground for 'legal transplants', which are defined as 'the moving of a rule or a system of law from one country to another'. ${ }^{37}$ In January 2017, the HCJP report wondered 'what can be done to increase the attractiveness of Paris as a litigation forum? This would require equipping our courts with the skills and organisational resources that would enable them to adequately meet the needs of business. This evolution would require at least three sets of reforms: (i) [adjusting] the

35. 'Inauguration de la chambre commerciale internationale à la Cour d'appel de Paris', 27 February 2018, available at: www.jss.fr/ Inauguration_de_la_chambre_commerciale_internationale_a_la_cour_d \%E2\%80\%99appel_de_Paris-1187.awp? AWPID98B8ED7F=C6235494BA513C285A321DF587C7D2D445C573 1D (last visited January 2019).

36. M. Prada, 'Rapport sur certains facteurs de renforcement de la compétitivité juridique de la place de Paris', March 2011, available at: www.textes.justice.gouv.fr/art_pix/1_Rapport_prada_20110413.pdf (last visited January 2019).

37. A. Watson, Legal Transplants: An Approach to Comparative Law (1974), at 106. rules of procedure to allow the use of English at the various stages of the proceedings (oral arguments, submissions, decisions) ..., (ii) [updating] the rules of procedures to add some evidentiary tools inspired by the Common Law (discovery, cross examination, etc.) ..., (iii) setting up special courts for cross-border civil and commercial disputes' ${ }^{38}$ The creation of international commercial courts thus tends to revitalise discussions on a convergence between common law and civil law systems for resolving international commercial disputes. ${ }^{39}$ To be successful, transplantation requires careful implementation. In particular, transposed rules should fit within the broader French legal culture and tradition. As HCJP pointed out, 'in any event, the goal is not to systematically transpose in France the rules and methods of the Common Law courts, and in particular of the London Commercial Court ... but to incorporate, into our legal system, a mechanism adapted to hearing international business law disputes'. ${ }^{40}$

Alternatively, the launch of international business courts can be an opportunity for 'rediscovering the wheel', ${ }^{41}$ or, in other words, a chance to revisit existing procedural rules so as to maximise their potential and effectiveness. Ultimately, this is the approach that HCJP has prioritised. As it noted, 'all these objectives must be achieved pragmatically, by paying close attention to the demands on international commerce ..., while complying with national procedural principles and rules, and, therefore - at least initially - without amending the laws currently in force, but simply optimising their application'. ${ }^{42}$ HCJP noted, indeed, that many rules currently laid down in the French Code of Civil Procedure (Code de procédure civile) and dealing with case management, production of evidence or hearings are still, today, 'significantly underused'. ${ }^{43}$ Therefore, it suggested that '[in order] to offer a credible judicial system to international litigants, the practice before our courts must be revised by making use of available procedural tools ...' ${ }^{44}$

\subsection{Key Adjustments: Language and Procedural Rules}

As highlighted previously, either through legal transplants or via a rediscovery of the wheel, adjustments may lead to progressive convergences in the way courts deal with international commercial litigation. The con-

38. HCJP Brexit Report, above n. 19, at 29-30.

39. More generally, about the convergence between civil law and common law systems, see, e.g., D. Oto-Peralías and D. Romero-Ávila, 'Legal Change within Legal Traditions and Convergence', in: D. Oto-Peralías and D. Romero-Ávila, Legal Traditions, Legal Reforms and Economic Performance. Contributions to Economics (2017), at 57-83; J. Armour, S. Deakin, P. Lele \& M. Siems, 'How Legal Norms Evolve: Evidence from a Cross-country Comparison of Shareholder, Creditor and Worker Protection', American Journal of Comparative Law 57 (2009), at 579-629.

40. HCP, Recommendations, above n. 9, at 12

41. U. Mattei, 'Efficiency in Legal Transplants: An Essay in Comparative Law and Economics', 14 International Review of Law and Economics 14 (1994), at 3-19 (quoting A. Schlesinger).

42. HCJP, Recommendations, above n. 9, at 12

43. Ibid., at 19

44. Ibid., at 19-20. 
vergence between legal systems has been described 'as a movement towards efficiency'. ${ }^{45}$ As Mattei noted, 'efficiency' may be defined as 'whatever legal arrangement "they" have that "we" wish to have because by having it they are better off". ${ }^{46}$ International law scholars have also explained the issue of convergence through the notion of 'acculturation', defined as 'the general process by which actors adopt the belief and behavioural patterns of the surrounding culture', and highlighted that 'this mechanism induces behavioural changes through pressures to assimilate ...' ${ }^{47}$ International commercial courts in France can be seen as being mainly a 'rediscovery of the wheel' exercise, with some limited legal transplants concerning the way proceedings are organised. In contrast, other EU member states have opted for more far-reaching procedural changes for their international commercial courts. For example, in its draft proposal, the Brussels International Business Court (BIBC) provides that, although the court remains a state court, the procedure will be based on the UNCITRAL Model Law on International Arbitration. Also, unlike ordinary proceedings before Belgian courts, appeal of BIBC decisions will not be possible. ${ }^{48}$ In France, key adjustments regard the use of the English language during the proceedings, ${ }^{49}$ and some procedural adjustments concerning the collection of evidence and organisation of hearings, the latter being clearly inspired by the common law tradition.

\subsubsection{Language}

The use of the English language is certainly one of the most innovative features of the French international commercial courts. The use of the English language is, indeed, essential to ensure the access of multinational corporations to the French judicial system. However, the use of English before the French international business courts also faced several issues. According to Article 2 of the French Constitution, the language of the French Republic is French. The Constitutional Council (Conseil constitutionnel) has specified that this rule applies to any public entity as well as to private parties entrusted with public service missions. ${ }^{50}$ Moreover, the Ordinance of Villers-Cotterêts ordered in 1539 by Francis I (François 1er) (and still in force today) requires all court documents to be drafted in French. Initially, the Ordinance intended to make all documents comprehensible to everyone, and promoted linguistic unification

45. Mattei, above n. 41

46. Ibid.

47. R. Goodman and D. Jinks, 'International Law and State Socialization: Conceptual, Empirical, and Normative Challenges', 54 Duke Law Journal 983 (2005).

48. Chambre des représentants de Belgique, Projet de loi instaurant la Brussels International Business Court, 15 May 2018, available at: www.lachambre.be/FLWB/PDF/54/3072/54K3072001.pdf (last visited January 2019).

49. A. Bailly and X. Haranger, 'Le tribunal de commerce et la Cour d'appel de Paris acceptent désormais les plaidoiries et les productions de pièces en anglais', AJ Contrat (2018), at 148.

50. Constitutional Council (Conseil constitutionnel), decision 2006-541 DC of 28 September 2006 relative à l'accord sur l'application de l'article 65 de la convention sur la délivrance de brevets européens. within the Kingdom of France (against Latin and other regional languages). In addition, although the French Code of Civil Procedure does not force judges to use interpreters (provided that they are familiar with the language spoken by the parties), ${ }^{51}$ courts have often been reluctant to admit foreign languages in practice. ${ }^{52}$ As a compromise between the necessity to comply with the above-cited texts and the need to facilitate the use of English at the various stages of the proceedings, new procedural rules of ICCP-CA and CIE now provide that ${ }^{53}$ procedural acts are drafted in French; documentary evidence may be submitted in English, without translation; and pleadings are conducted in French. However, parties, experts and third-party witnesses appearing before court, as well as legal counsels who are not French nationals and who are authorised to appear before the court, may use the English language; subject to the court's consent, any party may, at its own expense, arrange for a simultaneous interpretation of oral proceedings held in French; the final judgement is delivered in French but is accompanied by a swornEnglish translation to facilitate its immediate enforcement in other jurisdictions.

\subsubsection{Procedural Rules on Evidence-Gathering and Hearings}

As HCJP noted, the French Code of Civil Procedure 'clearly organises the production of evidence ..., but in this area, as in others, their implementation depends on the actions of the parties' and of the courts. ${ }^{54} \mathrm{CIE}$ and ICCP-CA protocols facilitate the admissibility of evidence. ${ }^{55}$ For example, statements by experts and other third parties can now be in typewritten form only. As regards hearings, HCJP highlighted that 'there is no obstacle to taking as much evidence at the hearing as the dispute requires and the parties desire. All that is needed therefore, at this stage as well, is an appropriate application of the rules of civil procedure, which are themselves sufficient'. ${ }^{56}$ Inspired by the common law tradition, the format of hearings is likely to change significantly. The hearings will be longer and may extend to several days, as judges may be keener to hear witnesses, parties and experts. Also, inspired by the English cross-examination process, ${ }^{57}$ rules provide that the judge submits to witnesses' questions he or she deems relevant to facts that are the subject of legally admissible evidence. Then, the judge can invite witnesses to answer questions from any of the parties. ${ }^{58}$ Proceedings will be subject to an imperative timetable detailing

51. Article 23 of French Code of Civil Procedure.

52. C. Kern, 'English as a Court Language in Continental Courts', Erasmus Law Review (2012), at 187-209.

53. ICCP-CA Protocol, above n. 1 (Arts. 2, 3 and 7) and CIE Protocol, above n. 3 (Arts. 2, 6 and 7).

54. HCJP, Recommendations, above n. 9, at 25

55. ICCP-CA Protocol, above n. 1 (Arts. 4 and 5) and CIE Protocol, above n. 3 (Arts. 5 and 6).

56. HCJP, Recommendations, above n. 9, at 26

57. O. Dufour, 'Paris part à la conquête du contentieux commercial international', Gazette du Palais, 13 February 2018.

58. ICCP-CA Protocol, above n. 1 (Art. 5.4.4) and CIE Protocol, above n. 3 (Art. 4.4.4). 
- among other things - when the parties have to appear in person or when written statements have to be submitted. ${ }^{59}$

\section{Looking to the Future While Keeping Our Ears to the Ground}

\subsection{Will All of This Work?}

'Give Paris one more chance', as the song says. ${ }^{60}$ The success of these initiatives will rest on several factors, some of which are listed here: CIE and ICCP-CA judges will first need to be able to deal with complex business cases swiftly and in English; they will have to adapt their practices accordingly; foreign litigants will need to be convinced by the added value and quality of the French international courts, in particular vis-à-vis other international commercial courts now mushrooming worldwide but also vis-à-vis arbitration often regarded as a flexible tool for resolving commercial disputes. The fact that - unlike other European specialised business courts - no high court fees apply before the ICCP-CA might be a clear incentive for litigants when bringing their disputes to France. Success of the CIE and ICCPCA will also depend on their visibility in the international arena. In July 2018, HCJP President Guy Canivet called on all French stakeholders to actively support these initiatives and invited them to promote French international commercial courts vis-à-vis their clients and within companies. ${ }^{61}$ The results of these lobbying exercises may become clearer in the years to come.

In the context of an ever-growing competition, French international business courts may also gain by departing from other jurisdictions by developing their own and original expertise. For example, as authors have interestingly pointed out, ${ }^{62}$ in the future, one added value (and perhaps a key competitive advantage) of the French international business courts might lie less in their ability to attract common law disputes - one may think that other common law jurisdictions like New York or Singapore will remain preferred litigation centres for international litigants with common law disputes - than in their ability to attract disputes relating to the many civil law systems existing around the world, for example in South America or Africa. Alternatively, French international business courts may benefit from specialisation in a few commercial sectors (such as banking, insurance or others) in which the court could ulti-

ICCP-CA Protocol, above n. 1 (Art. 4.3) and CIE Protocol, above n. 3 (Art. 3).

60. J. Richman, Give Paris One More Chance (2001).

61. M. Lartigue, 'Chambres internationales de Paris: appel à la mobilisation des juristes et des avocats français', Gazette du Palais, 10 July 2018, at

62. A. Hamelle and C. Jamin, 'Chambres internationales de Paris: encore un effort!', Semaine jurdique (19 November 2018), at 2110. mately develop their own knowledge and specific case law. ${ }^{63}$

Finally, one may still doubt that the mere existence of international commercial courts will be sufficient to make Paris an attractive centre for international litigation. ${ }^{64}$ Current initiatives should not remain isolated but be accompanied by other reforms. In particular, one stream of measures should seek to strengthen and modernise the French legal profession in the eyes of foreign litigants. For the past several years, for instance, proposals have burgeoned for the creation of a consolidated and renewed French legal profession (the so-called grande profession du droit) in which private practitioners (avocat) and in-house counsels (juriste d'entreprise) would enjoy a similar status and be subject to the same code of professional ethics. Unlike other countries, France still considers these two branches separate. For example, communications from in-house counsels are not protected by legal privilege (secret professionnel), as they are for private practitioners. Yet, as a 2011 report pointed out, the existence of a unified legal profession could be a source of international dynamism. ${ }^{65}$ The creation of international business courts was therefore certainly a first step, but France still needs to connect the other dots if the overarching objective is to improve the quality of its legal services in the eyes of foreign litigants.

\subsection{French International Business Courts: Judicial Labs for High-Quality Judiciary or Symptoms of a Multi-tiered Judicial System?}

The functioning of international commercial courts needs to be backed up with a pool of highly trained professionals able to navigate European private law, European civil procedure as well as business law and complex commercial matters. Therefore, side effects on the judiciary can already be foreseen with regard to the training and education of judges. This may notably lead to an upstream specialisation of the education delivered by the French National School for the Judiciary (Ecole Nationale de la Magistrature). In parallel, one may wonder whether the procedural innovations now in place before the CIE and ICCP-CA - notably the increasing role given to oral hearings and collection of evidence will serve as examples for the French judicial system as a whole and trigger an evolution in the attitude of other French courts. One interesting question is whether CIE and ICCP-CA will act as test cases - one may rather say as judicial labs - for modernising the French judicial system. Will the new judicial practices before the CIE and ICCP-CA remain an isolated phenomenon strictly

65. M. Prada, 'Rapport sur certains facteurs de renforcement de la compétitivité juridique de la place de Paris', March 2011, available at: www.textes.justice.gouv.fr/art_pix/1_Rapport_prada_20110413.pdf (last visited January 2019) (in French: 'l'existence d'une grande profession du droit est, en outre, porteuse de dynamisme international et n'est pas étrangère au rayonnement des professions d'origine anglo-saxonnes dans le monde', at 6). 
confined to these two courts? Conversely, is this the start of something new and broader with consequences for the French legal profession and the judiciary? Will CIE and ICCP-CA contribute to a more effective judicial system by driving up quality standards for the whole justice system? Or, on the contrary, will they widen the gap between, on the one hand, international commercial courts providing high-quality services for multinational corporations, and, on the other hand, ordinary courts with limited resources in charge of administering justice for citizens? Future developments will need to be carefully monitored to avoid the development of a two-tiered justice system. As of today, it is too early to predict whether these innovative business courts will have positive repercussions for the French judicial system. Yet one may already note an interesting divergence from the perspective of judicial policy between, on the one hand, French international business courts and, on the other hand, other (regular) courts. In particular, the increasing role given to oral hearings before the CIE and ICCP-CA seems somehow paradoxical when considering the shrinking space given to oral hearings before other courts. For example, a legislative proposal reforming the French judicial system went as far as to suggest the removal of hearings before high courts of first instance (Tribunal de grande instance), provided that parties agree. ${ }^{66}$

Concerns about the development of a dual-quality judicial system are not limited to France. As the first advocate general of the Belgian court of cassation stressed, in September 2018, concerning the BIBC, one should 'avoid a distortion between, on the one hand, justice for litigants, mostly foreigners, who will choose the BIBC and benefit from an adequate material environment and speedy decisions, and, on the other hand, that of the other citizens, who will have to be content with justice being done on obsolete premises, without adequate human resources to render justice within a reasonable time frame'. ${ }^{67}$

\subsection{Beyond Competition: Imagining a Collaborative EU Framework for Resolving International Commercial Litigation}

Like France, several EU member states are in the process of setting up international commercial courts. Should all of them be established, they will all compete to attract international disputes and thereby contribute to a fragmentation of the European offer for resolving international disputes; in other words, a patchwork of different rules and practices across jurisdictions will develop. This might impair the visibility and intelligibility of companies. Instead of competing, a solution could be to bring forward a more coherent structure at

66. 'Projet de loi de programmation 2018-2022 et de réforme pour la justice', JUST1806695L, Art.13.

67. Brussels Times, 'Brussels International Business Court May Generate two-speed Justice', 4 September 2018, available at: www.brusselstimes.com/belgium/justice/12423/brussels-internationalbusiness-court-may-generate-two-speed-justice (last visited January 2019). the EU level. In September 2018, a study for the EU Parliament proposed that a European commercial court (ECC) be established. ${ }^{68}$ The ECC could indeed present several advantages: it would be composed of commercial judges from all member states with different legal and cultural backgrounds, the court would operate as a 'truly international forum', and, as the report points out, it would, 'probably better than any national court, signal that it is neutral and impartial'. ${ }^{69}$ The ECC could also contribute to the attractiveness of the EU and European businesses. If the objective is ultimately to compete with major dispute resolution centres like New York, Singapore, Hong Kong or Abu Dhabi, one may realistically think that the ECC can be in a better position to compete internationally than any other international commercial courts set up at the level of member states.

Alternatively, another solution could be to imagine a network of European business courts (NEBC), placed under the authority of a General European commercial court (GECC). Under this framework, depending on the sector at stake, disputes would be allocated to a specific European business court. For example, international disputes relating to maritime law and shipping would be allocated to a specialised business court in, say, the Netherlands, with expertise in maritime law; IP or patent issues would be handled by a business court specialising in patent litigation and operating in Germany; disputes relating to banking would be handled by a specialised business court in France or Belgium; and so on. The GECC would act as the single point of entry for litigants and would then be in charge of channelling international disputes to the competent court(s). Since legal issues are often intertwined in complex commercial litigation, the GECC would also be in charge of dealing with cases in which multiple and cross-cutting legal issues are at stake. Surely, the idea of an NEBC will be difficult to implement as several (highly) sensitive legal and political obstacles would have to be resolved. However, it might now be the right time to think and be creative. The development of international business courts in the EU would certainly gain if these courts were no longer considered from the perspective of competition but rather in the light of a collaborative process implemented at the European level.

France has recently boosted its judicial system to make it more attractive in the eyes of multinational companies. It remains to be seen whether these new developments will be sufficient and whether they will respond to the expectations and concerns of foreign litigants. If

68. 'Building Competence in Commercial Law in the Member States', Study for the JURI Committee on the European Parliament, PE 604.980, September 2018, available at: www.europarl.europa.eu/thinktank/en/ document.html?reference=IPOL_STU(2018)604980 (last visited January 2019); see also X. Kramer, E. Themeli \& G. Antonopoulou, 'International Commercial Courts: Should the EU Be Next?- EP Study Building Competence in Commercial Law', 23 September 2018, available at: http:// conflictoflaws.net/2018/international-commercial-courts-should-theeu-be-next-ep-study-building-competence-in-commercial-law/ (last visited January 2019).

69. Ibid 
the objective is to compete with major international litigation hubs, one may wonder whether a more sustainable solution does not lie at the European level instead. Finally, the side effects of these innovative business courts on the judicial system as a whole should be anticipated carefully. In the future, international commercial courts may be used as laboratories for modernising procedural rules and judicial practices but, importantly, should not open the door to multi-tiered justice systems, where ordinary citizens would be left behind. 